WIDER Working Paper 2014/072

\title{
Disentangling the pattern of geographic concentration in Tunisian manufacturing industries
}

Mohamed Ayadi ${ }^{1}$ and Wided Mattoussi ${ }^{2}$

April 2014 
Abstract: In this paper, we examine the pattern of spatial concentration of manufacturing industries observed in Tunisia and explore the factors driving firms' choices of location at the provincial level. We consider specialization and competition indicators as the driving forces and also examine the extent to which location choice is related to centre business districts. We estimate the effect of the location variables on sector growth and productivity. Our results suggest that firms choose to locate in a specific governorate because of high local demand, which brings about transportation cost savings. Moreover, we find a concentration of activity in Greater Tunis where most growth in firms and employment are observed, while locating in littoral governorates enhances the productivity growth of governorate industries.

Urbanization economies in Tunisia encourage the emergence of virtuous circles in the transmission of innovative ideas, so firms can benefit from the proximity of other manufacturing units. Geographic concentration in Tunisian manufacturing industries is a kind of commercial relationship between the sectors rather than the division and the exploitation of technological complementarities between sectors.

Keywords: industrial concentration, concentration index, competition index, Tunisia JEL classification: D22, L25, R12, R32

Acknowledgements: This paper is one of a series of studies on industrial development in Africa produced in collaboration between the Africa Growth Initiative at Brookings, the African Development Bank (AfDB), and UNU-WIDER under their joint project 'Learning to Compete' (L2C).

The authors would like to thank Samia Mansour, and Daniel Zerfu for their great help in getting access to the firm level data on which the analysis has been performed; and also Carole Newman for her helpful comments.

${ }_{1}^{1}$ UAQUAP- ISG, University of Tunis, Tunisia, email: med.ayadi@gnet.tn (corresponding author); ${ }^{2}$ University of JendoubaLAREQUAD, email: wided.mattousse@gmail.com

This study has been prepared within the UNU-WIDER project 'Learning to Compete: Accelerating Industrial Development in Africa', directed by John Page.

Copyright (C) The Authors 2014

ISSN 1798-7237 ISBN 978-92-9230-793-6

Typescript prepared by Liisa Roponen at UNU-WIDER.

UNU-WIDER gratefully acknowledges the financial contributions to the research programme from the governments of Denmark, Finland, Sweden, and the United Kingdom.

The World Institute for Development Economics Research (WIDER) was established by the United Nations University (UNU) as its first research and training centre and started work in Helsinki, Finland in 1985. The Institute undertakes applied research and policy analysis on structural changes affecting the developing and transitional economies, provides a forum for the advocacy of policies leading to robust, equitable and environmentally sustainable growth, and promotes capacity strengthening and training in the field of economic, and social policy-making. Work is carried out by staff researchers and visiting scholars in Helsinki and through networks of collaborating scholars and institutions around the world.

UNU-WIDER, Katajanokanlaituri 6 B, 00160 Helsinki, Finland, wider.unu.edu

The views expressed in this publication are those of the author(s). Publication does not imply endorsement by the Institute or the United Nations University, nor by the programme/project sponsors, of any of the views expressed. 
'Markets favour some places over others, some places-cities, coastal areas, and connected countries_are favoured by producers (World Bank 2009). The spatial agglomeration of economic activities may generate cooperative relationships and high levels of interaction between actors, as well as knowledge spillover. Economic behaviour is influenced not only by formal incentives and institutions, but also by the interaction between the various economic agents involved in the activity (Amara and Ayadi 2009, 2013).

Economic theory suggests that an increase in a firm's productivity could well increase the productivity levels of neighbouring firms. If the characteristics of neighbouring firms affect the firm's own productivity, then one would expect industrial agglomeration to generate productivity spillovers, which shape the future productivity path of firms.

In addition to the productivity spillover, firms in clusters can experience other types of agglomeration effects. For instance, production costs may decline as firms deal with several competing suppliers. Moreover, larger scope for specialization and the division of labour may bring about large efficiency gains to the firms. An increase in the number of firms operating in the activity may increase the scope for competition, driving down prices.

According to the specialization hypothesis, namely the Marshall-Arrow-Romer (MAR) theory, firms' agglomeration of the same sector produces positive externalities and facilitate the growth of all manufacturing units within the sector. These advantages, which are inter-firms and intrasector, are based mainly on information sharing, a skilled labour market and intra-industry communication. According to Marshall (1920), the MAR theory increases the interaction between firms and workers, and speeds up the process of innovation and growth. As MAR, Porter (1990) underlines the importance of the knowledge externalities in economic growth. But, contrary to MAR theory, Porter supposes that local competition between firms has a positive effect on employment growth. Indeed, local competition facilitates innovation and supports the creation of new ideas.

Since the mid-1980s, Tunisia has implemented ambitious policies aimed at improving the productivity of firms and the efficiency of the labour force. However, these policies have been accompanied by an unequal spatial distribution of economic activities and large regional disparities in economic performance between coastal urban areas and rural interior ones (Ayadi and Amara 2011).

Against the specialization MAR hypothesis and Porter's local competition effects, we will consider the specific effects of urbanization economies. Urbanization economies generally refer to externalities occurring through the inter-industrial repercussions (knowledge spillovers). These relations encourage the emergence of virtuous circles in the transmission of innovative ideas, so firms can benefit from the proximity of the other manufacturing units. Following Batisse (2002), the existence of urbanization economies' positive impact can be explained as 'the reflection of the existing commercial relations between the sectors rather than the division and the exploitation of technological complementarities between sectors'.

In this paper, we examine the geographic concentration of industry in Tunisia and identify the main factors driving the observed pattern of spatial concentration. We address three important open research questions in the empirical literature that attempt to find evidence of agglomeration economies in developing countries: (i) do firms cluster? We illustrate the pattern of clustering using maps that exploit information on the exact location of firms; (ii) why firms cluster? We identify the factors driving firms' choices of location at the provincial level and their employment 
growth; and (iii) what are the benefits of clustering? We estimate the effects of aggregation and location variables on growth in productivity.

Our empirical analysis is based on three surveys on Tunisian manufacturing firms from 2004-06. These data are compiled from surveys conducted annually by the INS (Institut National de la Statistique) of Tunisia on all Tunisian manufacturing firms, conducted in 2004, 2005 and 2006. For the purpose of our econometric analysis, we aggregate the data to the sector-governorate level.

We find that even though specialization appears as an obvious phenomenon, it has a significant effect only on productivity growth. We have a specific 'urbanization economies' effect in the governorate industry localizations, but not a specialization one. Centre business districts (CBDs) offered the best economic incentives. Firms locate near each other to exploit the spillover effects of the principal CBDs located in costal governorates.

The paper is structured as follows. In section 2, we examine the current trends in regional and sectoral location-patterns of firms. In section 3, we present the estimation procedure to identify the determinants of localization. We sketch a firm location model as well as a governorate industry employment growth between 2004 and 2006. In section 4 we study the impact of localization choice on a firm's productivity. In particular we focus the analysis on the distinction between localization and urbanization externalities in order to explain regional inequalities. Section 5 concludes.

\section{Geographic concentration: where firms cluster?}

At the end of the 1980s, the Tunisian government adopted a structural adjustment programme the main purpose of which was to accelerate privatization and deepen integration with the European market. This programme improved the performance of firms and their technological and marketing capabilities (Ayadi et al. 2007). In turn, however, it created inequalities in economic performance and employment opportunities, particularly between coastal and interior regions. These regional disparities affect the spatial structure of economic activity. Indeed, factories have long been concentrated along Tunisia's coast, while the interior regions were isolated from these hubs of economic activity not only by distance but more significantly by a lack of infrastructure, transportation and information networks (Amara and Ayadi 2011, 2013). However, some sectors are more concentrated in specific areas.

We illustrate the pattern of clustering using maps that exploit information on the exact location of firms. Our empirical analysis to identify the localization determinants will be based on three waves of firm-level data using accounting, industrial, and exporting flows surveys on Tunisian manufacturing firms from 2004-06. These data are compiled from surveys conducted annually by the INS (Institut National de la Statistique) of Tunisia on all Tunisian manufacturing firms, totalling 2,308, 2,352 and 2,579 firms, respectively, in 2004, 2005 and 2006. The sectors and geographic heterogeneities motivate the aggregation of our data and our use of these two factors to analyse the determinants of firm's location.

We aggregate on sector-governorate, using 138 observations. We pool the observations on 24 governorates (Figure 2, in the Appendix) across 12 sectors. Some governorates-industries are omitted if industries are not founded in all governorates. 


\subsection{Regional disparities}

Figure 1 shows that in 2006, 16 governorates out of a total of 24 had less than 3 per cent of the total number of firms. They are essentially located in the interior zone of Tunisia. In contrast, two governorates (Tunis and Sfax) have 16.1 per cent and 19.4 per cent of the total number of firms, respectively. Figures 2 and 3, using aggregate governorates data between 1996 and 2011 (INS 2013), reveal that this regional disparity grew significantly over the 16 years between 1996 and 2011. This implies that there is both between- and within-region disparities in the concentration of firms.

Figure 1: Proportion of firms by governorate in 2006 (all firms)

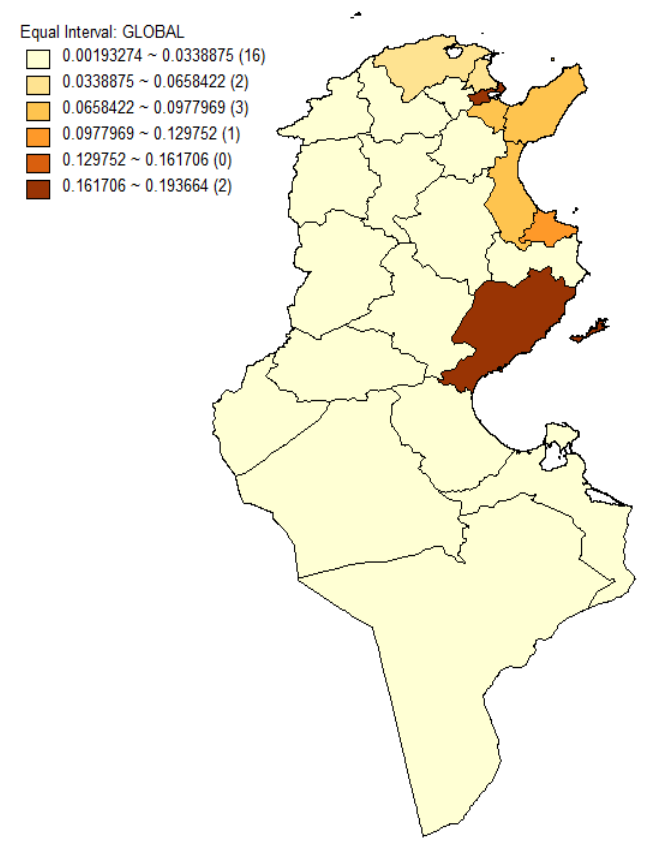

Source: Authors' calculus based on Enterprises Survey (2006).

We also consider the location pattern of new firms (Figure 2a). Here, we observe an increasing gap between western (interior) and eastern (littoral) regions. More specifically, Figure 2b illustrates

Figure 2: Trend in the number of firms between regions

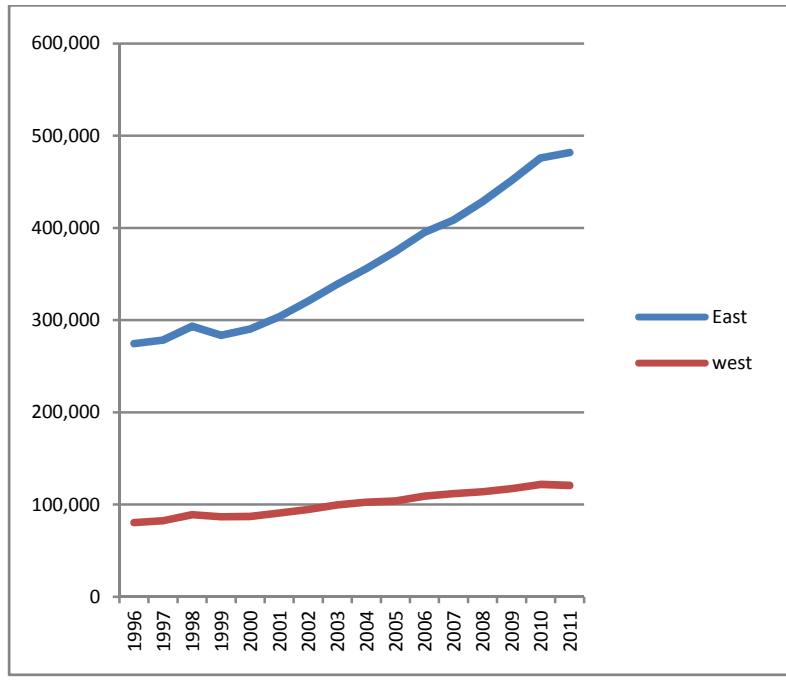

Panel A

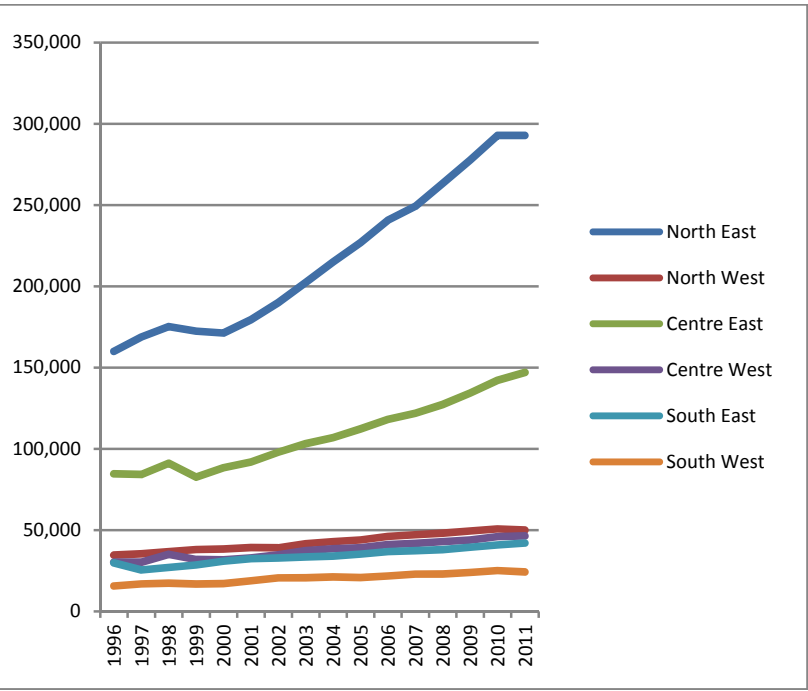

Panel B

Source: Authors' calculus based on INS (2013). 
Figure 3: Trend in the number of firms within regions

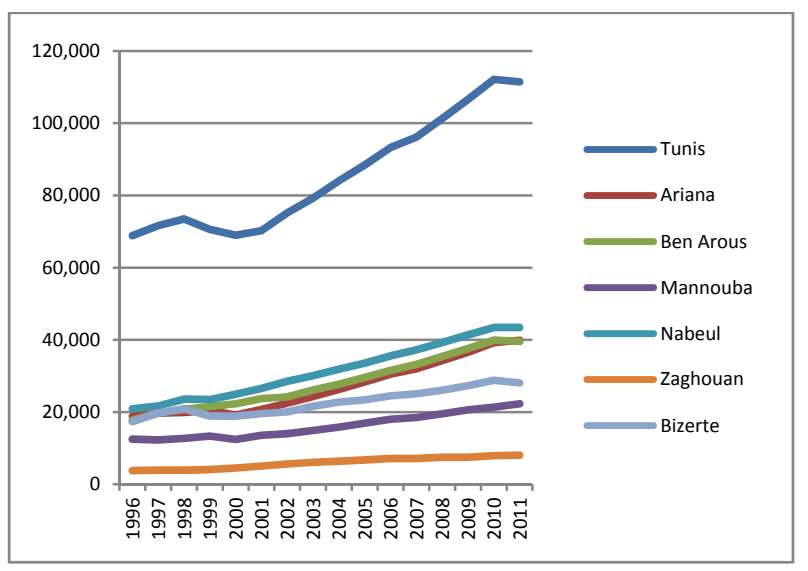

Panel A

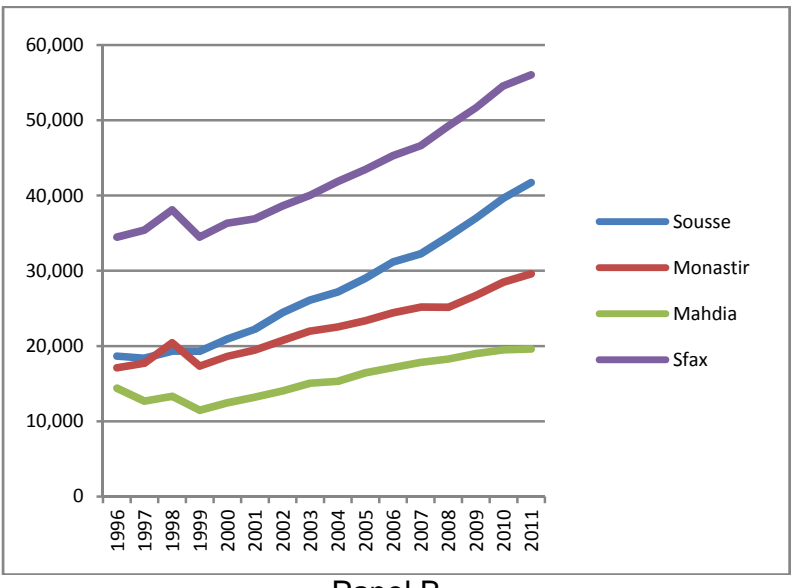

Panel B

Source: Authors' calculus based on INS (2013).

that more firms are created in the northeast and centre east regions as compared with other regions in Tunisia. The governorate of Tunis, however, is where most firms are created in the northeast region. In turn, when considering the centre east governorates, Sfax has the greatest number of new firms (see Figure 3).

Table 1 computes the frequency of firm number by governorate as the governorate number of firms on the total number of firms in Tunisia. Then the cumulative frequency is added in order to analyse firms' concentration in specific governorate. Table 1 shows that more than 83 PER CENT of firms are concentrated in the littoral region (Sfax, Tunis, Sousse, Monastir, Ben Arous, Nabeul Bizerte, Ariana). However, nearby 40 per cent of these firms are concentrated in the two CBDs of Tunis and Sfax (Figure 2). This further highlights that even within regions disparities exist (Figures 3).

Table 1: Regional disparities of global firm number

\begin{tabular}{lccc}
\hline Governorates & Frequency, $\%$ & Rank & Cumulate frequency, \% \\
\hline Sfax & 19.4 & 1 & 19.4 \\
Tunis & 17.9 & 2 & 37.2 \\
Monastir & 11.1 & 3 & 48.3 \\
Sousse & 9.7 & 4 & 57.9 \\
Ben Arous & 7.6 & 5 & 73.6 \\
Nabeul & 7.5 & 6 & 79.4 \\
Bizerte & 6.3 & 7 & 83.0 \\
Ariana & 3.6 & 8 & 85.7 \\
Medenine & 2.7 & 9 & 88.4 \\
Manouba & 2.7 & 10 & 90.8 \\
Gabès & 2.4 & 11 & 92.4 \\
Mahdia & 1.7 & 12 & 93.9 \\
Kairouan & 1.4 & 13 & 94.8 \\
Zaghouan & 0.9 & 14 & 95.6 \\
Gafsa & 0.8 & 15 & 96.3 \\
Jendouba & 0.7 & 16 & 97.0 \\
Kasserin & 0.7 & 97.6 \\
Béja & 0.6 & 17 & 98.2 \\
Le Kef & 0.6 & 98.8 \\
Tozeur & 18 & 99.2 \\
Sidi Bou & 0.6 & 99.6 \\
Tataouin & 0.5 & 20 & 100.0 \\
Siliana & 0.4 & 21 & \\
Kebili & 0.2 & 22 & 23 \\
Source: Autho & 24 & \\
\hline
\end{tabular}

Source: Authors' calculus based on Enterprises Survey (2006). 


\subsection{Sector disparities}

We extend the basic analysis to deal with the sectorial specificities. Indeed, Tunisian manufacturing products are mainly concentrated on textiles and clothing, which constitute almost 70 per cent of manufacturing products. However, a certain number of new products have emerged such as beam wires commanded by European mass-produce vehicles, electronic components, certain plastic products, essential oils, detergents, products for which the foreign demand has exhibited a rapid increase (Ayadi and Mattoussi 2013). This suggests that the regional disparities analysed above are very likely to be sectorial specific. We investigate the analysis conducted above for five sectors, notably, the textile/garment, footwear industries, the mechanical/electronic and electric industries, the chemical industries and the agrofood industries.

Figure 4 shows that growth in the number of new firms in the textile/garments sector is greater than other sectors; however the growth rate has stagnated in the last few years. The electric and electronic industry grew steadily, while the leather and shoes industry grew at a slower rate. However, for all other sectors (including the chemical and agro-food sectors) the number of firms has stagnated.

Figure 4: Trend in the number of firms by sector

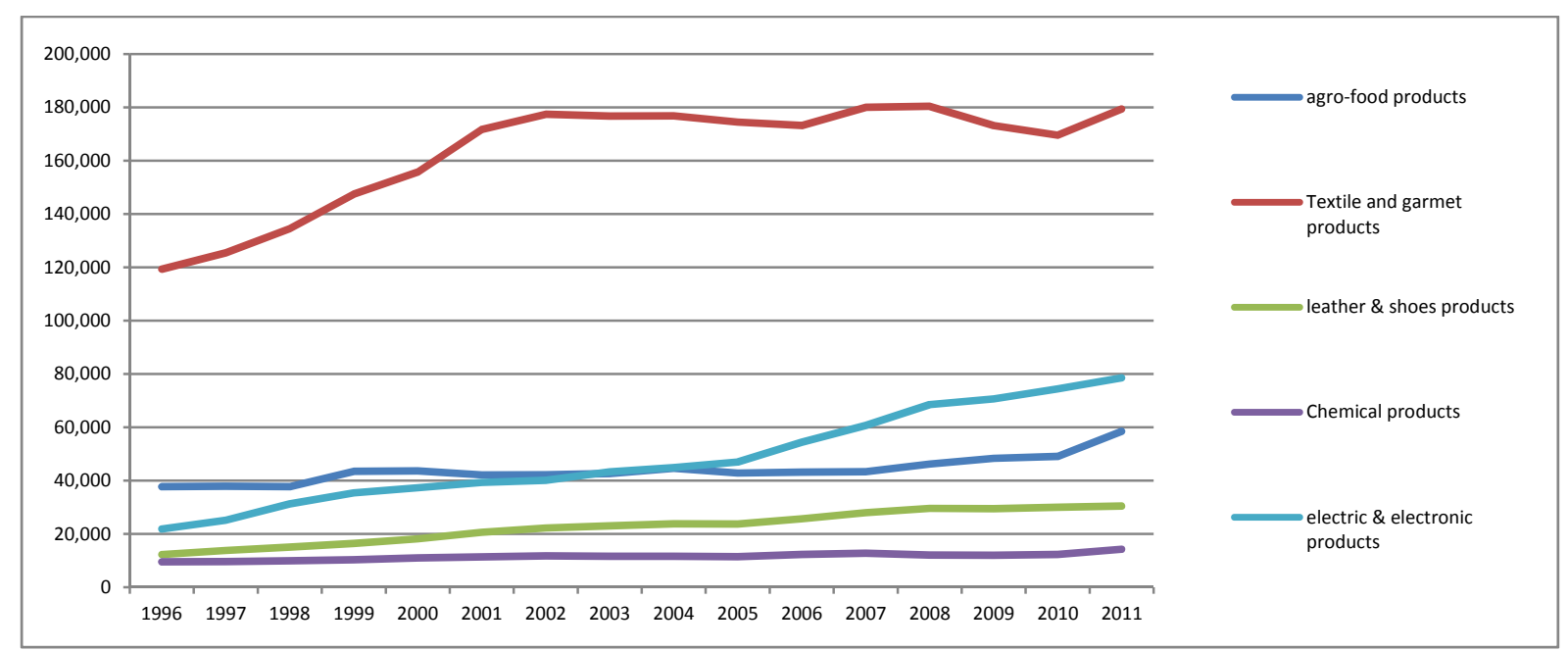

Source: Authors' calculus based on INS (2013).

Figure 5 illustrates the sector disparities between the 24 governorates. Textile firms are mainly located in Monastir provinces, while chemical firms are located in Ben Arous provinces. Most of the agro-food firms are located in Sfax and Nabeul governorates. Table A2 (in the appendix) provides some statistics confirming the previous conclusions. More than 30 per cent of textile firms are concentrated in Monastir governorate and more than 33 per cent of chemical firms are in Tunis (the administrative capital).

We distinguish between small and large firms in Table 2. Large firms are located closer to the Tunis governorate, while small firms are located around Sfax province. This suggests that in analysing the clustering of firms it is important to consider not only the number of firms but also their size. Thus in our analysis on the firms' choices of localization, we will use two different models, considering the 'growth in firm numbers' and the 'employment growth' as endogenous variables, respectively. 
Figure 5: Sector dispersement of firms among Tunisia's 24 governorates, 2006

Figure 5a: Textile firm concentration

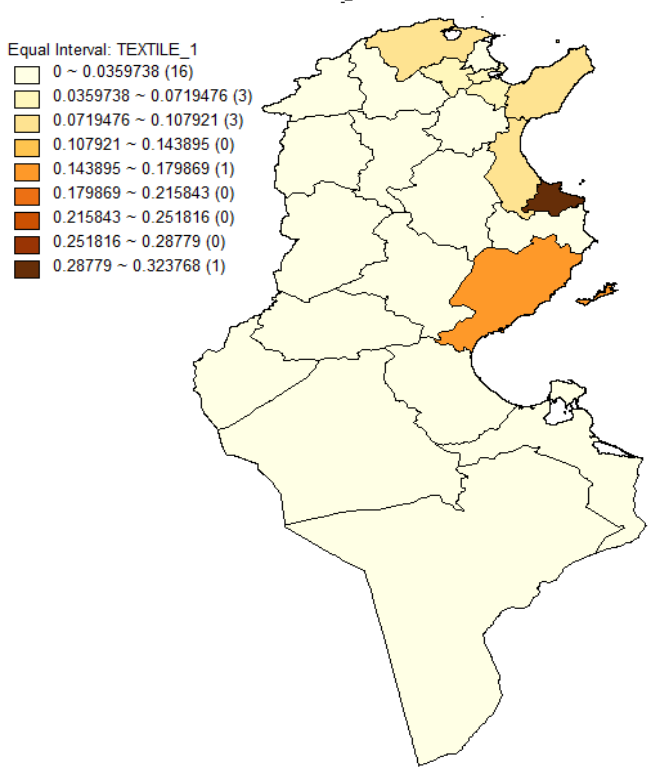

Figure 5c: Agrofood firm concentration

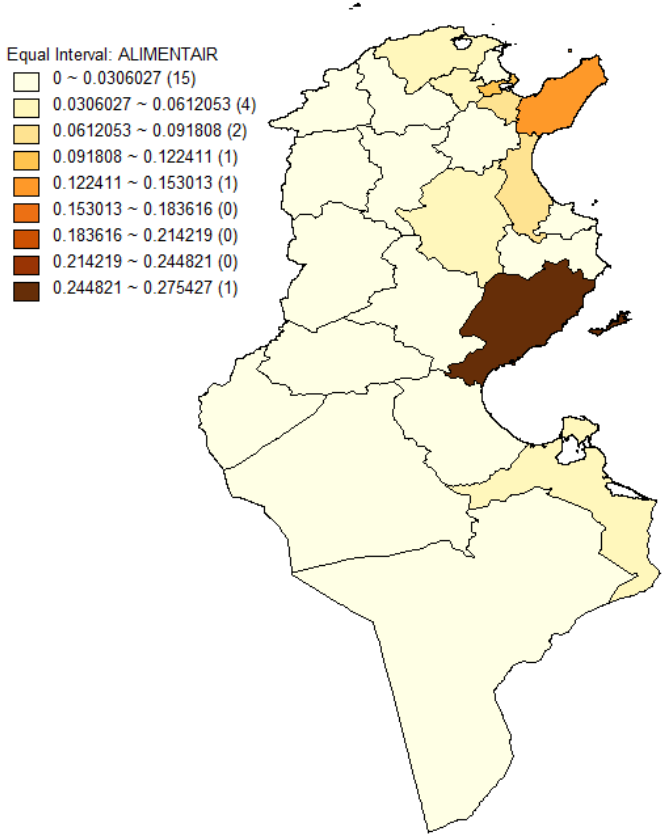

Figure 5b: Electric andelectronic firm concentration

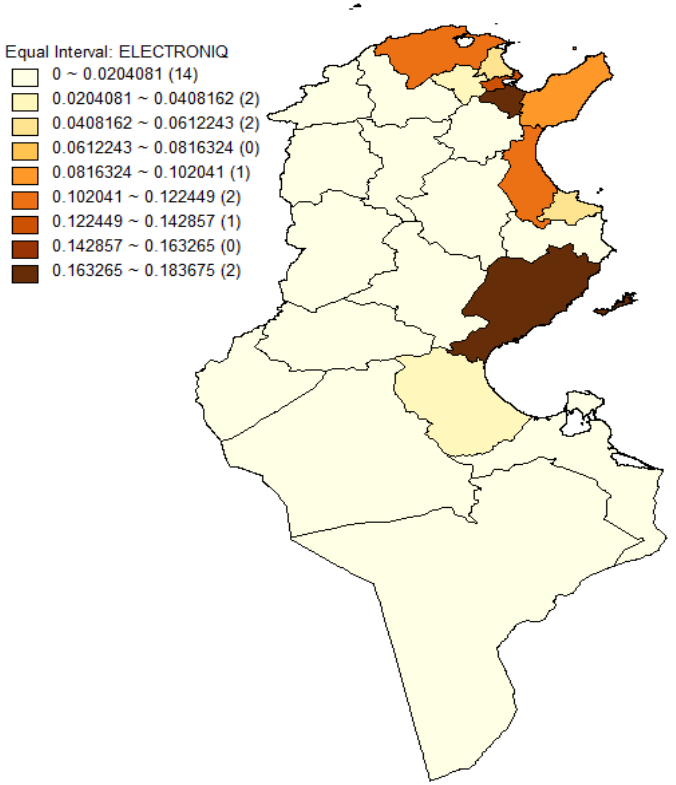

Figure 5d: Chemical firm concentration

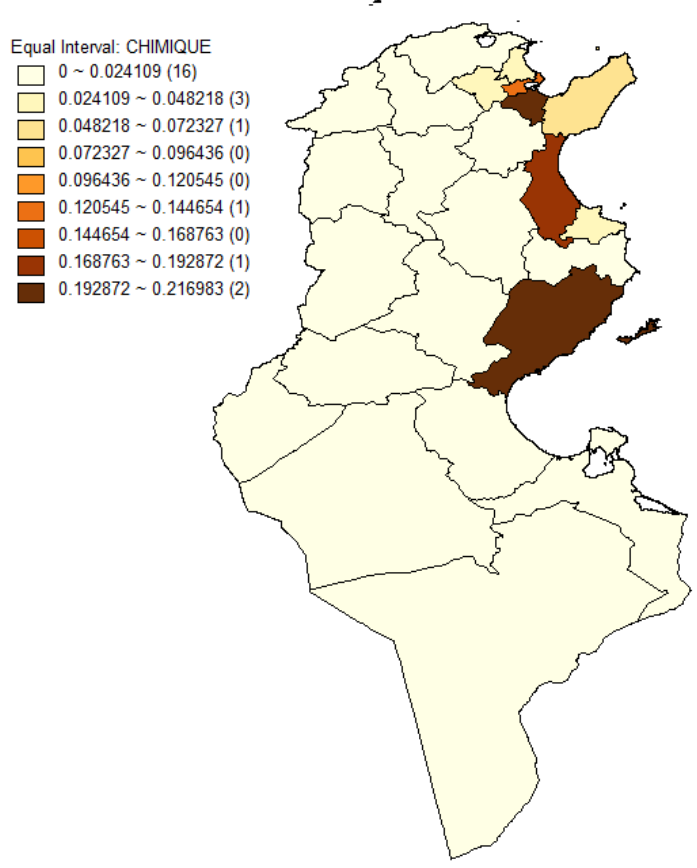

Source: Source: Authors' calculus based on Enterprises Survey (2006). 
Table 2: Regional disparities of global firm number (large and small sizes)

\begin{tabular}{|c|c|c|c|c|c|}
\hline \multicolumn{2}{|c|}{ Frequency of firm numbers } & \multicolumn{2}{|c|}{ Frequency of large firms } & \multicolumn{2}{|c|}{ Frequency of small firms } \\
\hline \multicolumn{2}{|c|}{ All firms } & \multicolumn{2}{|c|}{ >=30 employees } & \multicolumn{2}{|c|}{$<30$ employees } \\
\hline Governorate & Freq. & Governorate & Freq. & Governorate & Freq. \\
\hline Sfax & 19.3 & Tunis & 20.7 & Sfax & 27.7 \\
\hline Tunis & 17.9 & Monastir & 15.1 & Tunis & 14.3 \\
\hline Monastir & 11.1 & Sfax & 12.7 & Sousse & 8.9 \\
\hline Sousse & 9.7 & Sousse & 10.3 & Ben Arous & 7.2 \\
\hline Ben Arous & 7.6 & Nabeul & 8.3 & Nabeul & 6.2 \\
\hline Nabeul & 7.4 & Ben Arous & 8.0 & Monastir & 5.9 \\
\hline Bizerte & 6.4 & Bizerte & 7.0 & Bizerte & 5.6 \\
\hline Ariana & 3.6 & Ariana & 3.9 & Gabès & 3.7 \\
\hline Medenine & 2.8 & Manouba & 3.6 & Ariana & 3.3 \\
\hline Manouba & 2.7 & Medenine & 2.6 & Medenine & 3.0 \\
\hline Gabès & 2.4 & Mahdia & 1.5 & Kairouan & 2.1 \\
\hline Mahdia & 1.7 & Gabès & 1.3 & Mahdia & 1.9 \\
\hline Kairouan & 1.4 & Zaghouan & 0.9 & Manouba & 1.6 \\
\hline Zaghouan & 0.9 & Kairouan & 0.9 & Gafsa & 1.2 \\
\hline Gafsa & 0.8 & Le Kef & 0.6 & Jendouba & 1.2 \\
\hline Jendouba & 0.7 & Béja & 0.6 & Zaghouan & 1.0 \\
\hline Kasserine & 0.6 & Gafsa & 0.5 & Kasserine & 1.0 \\
\hline Béja & 0.6 & Jendouba & 0.4 & Tozeur & 1.0 \\
\hline Le Kef & 0.6 & Kasserine & 0.3 & Sidi Bou & 0.8 \\
\hline Tozeur & 0.6 & Tozeur & 0.3 & Tataouine & 0.7 \\
\hline Sidi Bou & 0.5 & Sidi Bou & 0.2 & Béja & 0.6 \\
\hline Tataouine & 0.4 & Siliana & 0.1 & Le Kef & 0.5 \\
\hline Siliana & 0.2 & Tataouine & 0.1 & Siliana & 0.3 \\
\hline Kebili & 0.2 & Kebili & 0.1 & Kebili & 0.3 \\
\hline
\end{tabular}

Source: Authors' calculus based on Enterprises Survey (2006).

\section{Estimation procedure to identify the determinants of localization: Why firms cluster?}

Two models are considered to analyse the factors that drive firms' location choice. We start with a firm localization model based on the growth in the aggregate firm numbers in industriesgovernorates couples, according to the aggregate characteristics of these industry and territory. Then we explain the growth of firms, approximated by employment growth, according to their own characteristics and those of their industry and territory, in order to analyse agglomeration determinants of firms' growth. We emphasize in particular the ability of the territory to provide a rich and dense knowledge environment. We also propose to evaluate whether firms benefit more from externalities intra industries or externalities inter industries to develop (Hichri et al. 2013).

\subsection{Factors of firms localization choices}

We explain the localization choices of firms according to their own characteristics, the characteristics of the firm's sector and location. Factors we believe to be the main factors affecting the clustering of a firm are the following: 
- Aggregation factors: We emphasize in particular the ability of the location to provide a rich and dense knowledge environment. We consider then a specialization indicator referring to MAR theory, and a competition indicator, referring to Porter theory.

- Urbanization economic factors: We extend our factor in order to analyse the effects of urbanization economies, referring to Jacobs's analysis. Jacobs (1969) considers that knowledge externalities are associated with the diversity of neighbour industry-industries. $\mathrm{He}$ observes that interaction and exchanges between industries in CBDs facilitate the development of innovation between industries and attract more prosperous firms and entrepreneurs. Then we will add dummies on CDBs (Tunis and Sfax) and on the urbanlittoral zone as urbanization economic factors.

- Economic factors: They include magnitude of firms' capital (capital), firm's revenue (rev), skilled employees share (wtech), total number of employees (emp) and the exporting share per governorate (parexp).

\section{1.a Aggregation factors}

Specialization index

According to the specialization hypothesis, firm agglomeration of the same sector produces positive externalities and facilitates the growth of all manufacturing units within the sector. These advantages, which are inter-firms and intra-sector, measured by specialization index, are based mainly on information sharing, a skilled labour market and intra-industry communication. According to the MAR theory, specialization increases the interaction between firms and workers, and speeds up the process of innovation and growth.

The specialization index considers the share of sector $j\left(E m p_{j, t}\right)$ in the total employment of region $r\left(E m p_{r, t}\right)$ against the share of the total employment in sector $j\left(E m p_{j, t}\right)$ in the total employment at the national level $\left(E m p_{N, t}\right)$ at period $t$.

$$
\text { Specialization index } x_{j, t}=\frac{E m p_{j r, t} / E m p_{r, t}}{E m p_{j N, t} / E m p_{N, t}}
$$

It gives the relative weight of each specific sector in the region compared to the national level. This index increases if the sector has an important effect at the regional level. Specialization will have a positive effect on regional economic growth as long as there are externalities between industries.

\section{Local competition index}

As in MAR, Porter (1990) underlines the importance of the knowledge externalities in economic growth. But contrary to the MAR theory, Porter supposes that local competition between firms, measured by competition index, has a positive effect on employment growth. Indeed, local competition facilitates innovation and supports the creation of new ideas.

Following Batisse (2002), we defined the local competition index for sector $s$ in region $r$ at time $t$ as:

$$
\text { Specialization index } x_{j, t}=\frac{E m p_{j r, t} / E m p_{r, t}}{E m p_{j N, t} / E m p_{N, t}}
$$

where $n b r e_{j r, t}$, and $n b r e_{j, \mathrm{t}}$ are, respectively, the number of firms in sector $j$ at delegation $r$ and at national level, respectively, at period $t$. 


\section{1.b Urbanization economics effects}

Table A1, resuming the specialization index by sector and governorate, illustrates the following features of industry specialization in Tunisia: (i) Exporting sectors (electronic, textile and chemical) are concentrated in the littoral regions (Ariana, Ben Arous, Bizerte, Sousse, Monastir, Mahdia). (ii) Only products associated with local markets are more diversified. (iii) The interior governorates (Gafsa, Tozeur, Sidi Bouzid, Kasserine, Kebili, Beja, Siliana) have a limited number of industrial units. Table A1 on "specialization index" concludes, perhaps surprisingly, that Kasserine is a specialized governorate in the chemical industries and Tataouine a specialized governorate in agro-food industries. However, in reality there is only one chemical unit in Kasserine and a few agro-food industrial units are located in Tataouine. But these units account for a large proportion of employment in these regions. This highlights the fact that the specialization index by its construction may classify an industry as being specialized in a particular region where manufacturing employment is low in general. To correct this bias, we add to our factors dummy variables on 'urbanization economies', illustrated by CBDs and littoral zones dummies.

Urbanization economies generally refer to externalities occurring through the inter-industrial repercussions (knowledge spillovers). These relations encourage the emergence of virtuous circles in the transmission of innovative ideas, so that firms benefit from the proximity of other manufacturing units. Following Batisse (2002), we consider that the existence of a positive impact of urbanization economies can be explained as 'the reflection of the existing commercial relations between the sectors rather than the division and the exploitation of technological complementarities between sectors'. Thus we added specific dummies on CDBs and on urbanlittoral zones, as well as sector specificities.

\subsection{Firm localization model}

For a country like Tunisia, where the industrial structure is characterized by a small number of large plants and a large number of firms of small sizes, then an analysis of the growth in the number of firms in each industry-territory is a relevant starting point. To explain why firms cluster, we estimate a model measuring the effects of governorate characteristics on the growth in the number of firms, referring to the firm's entrance and death, in each sector-territory. Plummer (2010) considers that 'the survivability of a new firm is not independent from the performance, growth, and survivability of nearby firms'.

To focus on the growth in the aggregate number of firms in each governorate industry, we define $Y_{g s, t}$ as the number of firms in sector $s$ in governorate $g$ and time period $t$. Then governorate industry growth measure will be:

$$
\text { FirmGrowth }{ }_{g s, t}=\log \left(Y_{g s, t}\right)-\log \left(Y_{g s, t-1}\right)
$$

Our firm localization model will be:

$$
\text { FirmGrowth gs,t }=\alpha+\beta_{1} \cdot \log \left(Y_{g s, t-1}\right)+\beta_{2} X_{g s, t-1}+\beta_{3} W_{g s, t-1}+\in g s, t
$$

Where Xgs,t-1 a vector of firms characteristics (including capital, revenue, share of exporting firms, employment size, share of skilled workers). $W_{g s, t-1}$ is a vector of regional characteristics (including sfax_dummy, tunis_dummy, littoral_dummy, specialization index and competition index). Table 3 illustrates the estimate results of the localization model.

Table 3 reveals that the 'specialization indicator' has no significant effect. However, 'competition' has a significant and positive effect. The number of firms tends to increase in more 
competitive areas than in specialized ones. On the other hand the littoral and Sfax dummies have positive and significant effects on provincial attraction, implying that firms are mainly concentrated around littoral zones involving all Tunisian CBDs. In Tunisia, CBDs offer better economic incentives for small firms. The localization choice therefore may be motivated by either 'urbanization' externalities or the promise of knowledge spillovers.

Table 3 also illustrates that growth in the number of firms is higher where the initial number of firms is low. In other words, governorate industries with an initially high number of firms, leading to greater competition, experience lower growth rates, suggesting that competition might be a deterrent to clustering. Capital, income, employment and exporting status do not have a statistically significant effect.

Table 3: Estimates of localization determinants

\begin{tabular}{|c|c|c|c|c|}
\hline \multirow[b]{2}{*}{ Variables } & \multicolumn{4}{|c|}{ Growth in the number of firms } \\
\hline & Model (1) & Model (2) & Model (3) & Model (4) \\
\hline Number of firms & $\begin{array}{l}-0.0439 \star \star \star \\
(0.0057)\end{array}$ & $\begin{array}{l}-0.0441^{\star \star \star} \\
(0.0058)\end{array}$ & $\begin{array}{l}-0.0421^{\star * \star} \\
(0.0058)\end{array}$ & $\begin{array}{l}-0.0423^{\star \star \star} \\
(0.0058)\end{array}$ \\
\hline Capital & $\begin{array}{l}-3.75 e-09 \\
(1.43 e-08)\end{array}$ & $\begin{array}{l}-3.42 \mathrm{e}-09 \\
(1.43 e-08)\end{array}$ & $\begin{array}{l}-5.96 e-09 \\
(1.42 e-08)\end{array}$ & $\begin{array}{c}-5.57 e-09 \\
(1.42 e-08)\end{array}$ \\
\hline Revenue & $\begin{array}{c}4.04 \mathrm{e}-09 \\
(8.29 \mathrm{e}-09)\end{array}$ & $\begin{array}{c}4.00 \mathrm{e}-09 \\
(8.32 \mathrm{e}-09)\end{array}$ & $\begin{array}{c}5.39 \mathrm{e}-09 \\
(8.27 \mathrm{e}-09)\end{array}$ & $\begin{array}{c}5.45 e-09 \\
(8.29 \mathrm{e}-09)\end{array}$ \\
\hline Employment size & $\begin{array}{l}-7.98 \mathrm{e}-06 \\
(0.0008)\end{array}$ & $\begin{array}{l}-0.000113 \\
(0.0008)\end{array}$ & $\begin{array}{l}0.000359 \\
(0.0008)\end{array}$ & $\begin{array}{l}0.000205 \\
(0.0009)\end{array}$ \\
\hline Exporting & $\begin{array}{c}0.0410 \\
(0.270)\end{array}$ & $\begin{array}{c}0.0205 \\
(0.275)\end{array}$ & $\begin{array}{c}0.0613 \\
(0.269)\end{array}$ & $\begin{array}{c}0.0264 \\
(0.273)\end{array}$ \\
\hline Sfax_dummy & $\begin{array}{l}1.938^{\star \star \star} \\
(0.517)\end{array}$ & $\begin{array}{l}1.895^{\star \star \star} \\
(0.527)\end{array}$ & $\begin{array}{l}1.983^{\star \star *} \\
(0.514)\end{array}$ & $\begin{array}{l}1.911^{\star \star \star} \\
(0.523)\end{array}$ \\
\hline Littoral_dummy & $\begin{array}{l}0.932^{\star \star \star} \\
(0.204)\end{array}$ & $\begin{array}{l}0.933^{\star \star \star} \\
(0.204)\end{array}$ & $\begin{array}{l}0.965^{\star \star \star} \\
(0.203)\end{array}$ & $\begin{array}{l}0.970 * \star * \\
(0.204)\end{array}$ \\
\hline Tunis_dummy & $\begin{array}{c}0.634 \\
(0.417)\end{array}$ & $\begin{array}{c}0.666 \\
(0.425)\end{array}$ & $\begin{array}{c}0.608 \\
(0.415)\end{array}$ & $\begin{array}{c}0.663 \\
(0.421)\end{array}$ \\
\hline Wtech & $\begin{array}{l}-0.463 \\
(0.564)\end{array}$ & $\begin{array}{l}-0.490 \\
(0.569)\end{array}$ & $\begin{array}{l}-0.220 \\
(0.578)\end{array}$ & $\begin{array}{l}-0.248 \\
(0.580)\end{array}$ \\
\hline Specialization Index & & $\begin{array}{c}0.0266 \\
(0.0603)\end{array}$ & & $\begin{array}{c}0.0475 \\
(0.0608)\end{array}$ \\
\hline Competition Index & & & $\begin{array}{c}0.0491^{*} \\
(0.0290)\end{array}$ & $\begin{array}{c}0.0535^{\star} \\
(0.0295)\end{array}$ \\
\hline Constant & $\begin{array}{c}0.273 \\
(0.452) \\
\end{array}$ & $\begin{array}{c}0.277 \\
(0.453) \\
\end{array}$ & $\begin{array}{l}-0.139 \\
(0.510)\end{array}$ & $\begin{array}{l}-0.169 \\
(0.512) \\
\end{array}$ \\
\hline Observations & 139 & 139 & 139 & 139 \\
\hline R-squared & 0.481 & 0.482 & 0.492 & 0.495 \\
\hline
\end{tabular}

Note: Standard errors in parentheses, ${ }^{* \star \star} p<0.01 .{ }^{* \star} p<0.05 .{ }^{*} p<0.1$

\subsection{Industry growth across localities}

We apply the Glaeser et al. (1992) model of employment growth in cities in order to analyse governorate industry growth. We do not limit ourselves to the growth in firm numbers between sectors and localities. We consider firm magnitude as measured by employment growth rates by 
sector and locality. We define $E_{g, t}$ as the employment magnitude of sector $s$ in governorate $g$ and at period $t$. The governorate industry employment growth measure is:

$$
\text { EmpGrowth } g s, t=\log \left(E_{g s, t}\right)-\log \left(E_{g s, t-1}\right)
$$

We estimate the model by measuring the effects of governorate characteristics on the governorate's employment growth. Industrial employment growth of a governorate is measured by the variation of employment. Among the many possible factors which we believe to affect this magnitude, we consider the same factors used in the previous model, with the exception of the lag of employment (as compared with the lag of the number of firms in the previous model). The 'specialization' and 'competition indices help to test the evidence on MAR and Porter dynamic externalities. The remaining variables control for the characteristics of the firms' environment.

We model employment growth of industries across localities as follows:

$$
\text { EmpGrowth }_{g s, t}=\alpha+\beta_{1} \cdot \log \left(E_{g s, t-1}\right)+\beta_{2} X_{g s, t-1}+\beta_{3} W_{g s, t-1}+\epsilon_{g s, t}
$$

Table 4 illustrates an ordinary least square estimation of the determinants of the employment growth across governorate industries as in the equation above. High initial employment in a governorate industry lowers the growth rate of employment in the industry concerned. This is consistent with our findings for the relationship between the growth in the number of firms and the initial number of firms in the governorate industry. One possible explanation is that labour demand is higher in locations where industries are already heavily concentrated, increasing the cost of labour and leading to lower firm entry and employment generation.

Table 4: Governorate industry employment growth between 2004-06

\begin{tabular}{lcccc}
\hline \multirow{2}{*}{ Variables } & \multicolumn{4}{c}{ Growth of governorate industry employment } \\
\cline { 2 - 5 } employment & Model $(1)$ & Model $(2)$ & Model $(3)$ & Model $(4)$ \\
\hline \multirow{2}{*}{ productivity } & $-0.00238^{\star \star \star}$ & $-0.00201^{\star \star \star}$ & $-0.00158^{\star \star \star}$ & $-0.00141^{\star \star}$ \\
& $(0.0006)$ & $(0.0006)$ & $(0.0006)$ & $(0.0006)$ \\
export & $-0.194^{\star \star \star}$ & $-0.175^{\star \star}$ & $-0.149^{\star \star}$ & $-0.141^{\star \star}$ \\
& $(0.0739)$ & $(0.0736)$ & $(0.0687)$ & $(0.0690)$ \\
Tunis_dummy & 0.108 & 0.157 & 0.147 & 0.173 \\
& $(0.155)$ & $(0.155)$ & $(0.143)$ & $(0.144)$ \\
Share of skilled workers & $0.773^{\star \star}$ & $0.653^{\star}$ & $0.895^{\star \star \star}$ & $0.822^{\star \star}$ \\
& $(0.355)$ & $(0.356)$ & $(0.328)$ & $(0.333)$ \\
Specialization index & $-1.237^{\star \star}$ & $-1.100^{\star \star}$ & -0.618 & -0.573 \\
& $(0.547)$ & $(0.545)$ & $(0.519)$ & $(0.520)$ \\
Competition index & & $-0.116^{\star \star}$ & & -0.0652 \\
& & $(0.0569)$ & & $(0.0541)$ \\
Constant & & & $0.126^{\star \star \star}$ & $0.120^{\star \star \star}$ \\
& & & $(0.0256)$ & $(0.0261)$ \\
Observations & $0.827^{\star}$ & $0.824^{\star \star}$ & -0.119 & -0.0720 \\
R-squared & $(0.419)$ & $(0.414)$ & $(0.431)$ & $(0.432)$ \\
\hline
\end{tabular}

Note: Standard errors in parentheses ${ }^{\star \star \star} p<0.01$, ${ }^{* \star} p<0.05,{ }^{*} p<0.1$. 
Control variables have the expected signs. Employment growth decreases when either the productivity of the governorate industry or the proportion of skilled workers increases. We also find that employment growth increases for governorate industries near Tunis, which supports the existence of an urbanization externality. In turn, the Tunis dummy has a statistically significant effect, but not the Sfax dummy, so that Tunis as the capital of the country has benefited from the political dominance of networks centred around the Ben Ali regime. Thus larger-sized factories (and employment prospects) are motivated to be nearer Tunis City.

The results on externalities reveal some striking findings. Heavily specialized industries exhibit a slower growth in employment. This is consistent with our finding that an initially high level of employment leads to slower growth in an industry's employment rate. This result is, however, in contrast to the predictions of the MAR model: the coefficient on the 'competition index' is positive and statistically significant. An increase in the number of workers in a governorate industry relative to the national average leads to higher growth in employment in that governorate industry employment, which is in line with the Porter externality hypothesis. It follows that 'competition increases the governorate industry employment growth rate.

When we use all the measures of externalities simultaneously, the results remain statistically significant for the competition index. 'Competition' within the governorate industry continues to exert a positive influence on the growth in employment and the coefficient barely changes. However, the 'specialization' effect is still negative but is statistically insignificant. The results on dynamic externalities are in line with the model Porter but not with the MAR model.

\section{Estimation procedure to identify the effect of localization on productivity}

In this section we consider the effect of agglomerative forces on sector productivity growth (productivity per employee).

$$
\text { ProdGrowth gs.t }=\alpha+\beta_{1} \log \left(P_{\text {gs.t }-1}\right)+\beta_{2} X_{\text {gs.t }-1}+\beta_{3} W_{\text {gs.t }-1}+\epsilon \text { gs.t }
$$

where: ProdGrowth gs.t $=\log \left(P_{g s . t}\right)-\log \left(P_{g s . t-1}\right)$. $P_{g s . t}$ the productivity per employee (output per employee) magnitude of sector $s$ in province $g$ and at period $t . X_{g s . t-1}$ and $W_{g s . t-1}$ are the same variables as in the previous models, leading to economic factors, urbanization economics and aggregate factors of sector $s$ in governorate $g$.

Table 5 presents the findings of the pproductivity equation. High initial productivity in a governorate industry reduces productivity growth. On the other hand, productivity decreases in governorate industries involved in exporting activity which is in line with Ayadi and Mattoussi (2013).

The second column shows that governorate industry specialization has a positive and statistically significant effect on productivity growth which supports the MAR view. However, governorate industry competition reduces productivity growth. The littoral dummy has a positive and significant effect. Governorate industries in the littoral governorate are exposed to a greater concentration of knowledge, and so this result suggests within-industry knowledge spillovers. 
Table 5: Estimates of productivity growth

\begin{tabular}{lccc}
\hline \multirow{2}{*}{ Variables } & \multicolumn{3}{c}{ Growth of productivity } \\
\cline { 2 - 4 } & Model $(1)$ & Model $(2)$ & Model $(3)$ \\
\hline Productivity & $-0.504^{\star \star \star}$ & $-0.495^{\star \star \star}$ & $-0.490^{\star \star \star}$ \\
Export & $(0.0649)$ & $(0.0644)$ & $(0.0642)$ \\
& -0.343 & $-0.465^{\star}$ & $-0.504^{\star \star}$ \\
Littoral dummy & $(0.236)$ & $(0.241)$ & $(0.242)$ \\
& $0.376^{\star \star}$ & $0.367^{\star \star}$ & $0.331^{\star}$ \\
Specialization index & $(0.178)$ & $(0.176)$ & $(0.177)$ \\
Competition index & & $0.107^{\star \star}$ & 0.0855 \\
& & $(0.0527)$ & $(0.0546)$ \\
Constant & & & -0.0369 \\
& & & $(0.0257)$ \\
Observations & & $5.094^{\star \star \star}$ & $5.203^{\star \star \star}$ \\
R-squared & $5.301^{\star \star \star}$ & $(0.694)$ & $(0.695)$ \\
\hline
\end{tabular}

Note: Standard errors in parentheses, ${ }^{* \star} p<0.01 .{ }^{* \star} p<0.05 .{ }^{*} p<0.1$

\section{Summary}

Our estimation results suggest that it is more competition than specialization which contributes to employment growth. Gleaser et al. (1992) advance that it is regional specialization and not dynamic externalities which contribute to growth. Regional specialization enables specialized labour to move easily between firms without moving between governorates. For example, for the textile and electronic tools industries there is a large degree of specialization. Our findings suggest that this specialization contributes to governorate industry productivity growth, but not employment growth which is correlated with the governorate competition index. We also find that locating in Greater Tunis has a positive and significant effect on the growth in the number of firms and in employment, while localization in littoral governorates (where principal Tunisian CBS are located) contributes to productivity growth. Henderson (1986) refers to these effects as 'urbanization' externalities. We find that they are also present in the Tunisian case. Our results could also be attributed to the fact that firms located in CBDs are offered better economic incentives and may therefore experience productivity spillovers as a result. Tunisian authorities have not had strong political initiatives to develop new CBDs. This has contributed to regional inequality increases during the last five decades, but also suggests that there may be some missed opportunities in terms of productivity spillovers.

\section{Conclusion and policy recommendation}

The Tunisian structural adjustment programme has increased firm performance and their technological capabilities, but it has created a growing inequality in economic performance and employment opportunities between coastal and interior regions. This regional disparity has affected the spatial structure of economic activity. More than 83 per cent of firms are concentrated in the littoral region, while 40 per cent of these firms are concentrated in two CBDs-Tunis and Sfax. As well as the geographic concentration of firms in general, there is also a concentration of sectors in certain regions. For example, textile firms are mainly located in Monastir provinces, while chemical firms are located in Ben Arous provinces and most of agrofood firms are rather located in Sfax and Nabeul governorates. 
Based on a specialization aggregate index, we find that exporting sectors are mainly concentrated in littoral regions, and only products associated with local demand are more diversified. However, interior governorates have limited number of industrial units.

We estimated a model measuring the effects of the characteristics of governorates on the economic magnitude of the governorate measured by the number of firms. We observe that the specialization indicator has no significant effect. However, the competition index has a significant and positive effect, implying that the number of firms tends to increase in a more competitive area than in specialized ones. The littoral and Sfax dummies also have positive and significant effects on provincial attraction. To consolidate this conclusion, we applied the Glaeser et al. (1992) model of employment growth in cities to analyse governorate industry growth. We note that the industries which are heavily concentrated exhibit a slower growth. This result is opposite to the predictions of the MAR model. In Tunisian industries, geographical specialization reduces employment growth. However, the impact of the competition index is positive and statistically significant. An increase of workers in a governorate industry relative to the national average leads to higher employment growth in that governorate industry, which is consistent with Porter's externality hypothesis.

In order to evaluate the effects of clustering, we identified the effect of localization on productivity, using a productivity growth model. Our findings suggest that high initial productivity in governorate industry reduces productivity growth and productivity decreases if the governorate industries are exporters. We also find that location in Greater Tunis has a positive and significant effect on firm growth. Localization in littoral governorate (where principal Tunisian CBS are located) contributed to productivity growth of governorate industries. Based on Henderson (1986) we refer to these effects as 'urbanization' externalities. In Tunisia the CBDs offered better economic incentives essentially for small firms, but no strong political actions have been taken to develop new CBDs. Thus, to reduce regional economic inequalities, we have to start by creating infrastructure and by developing new CBDs in the less economically developed regions. These are the principal incentives to the localization choices of firms and new industries.

Indeed, factories have long been concentrated along Tunisia's coast, while the interior regions were isolated from these hubs of economic activity not only by distance but, more significantly, by a lack of infrastructure, transportation and information networks (Amara and Ayadi 2011, 2013). Then to reduce inequalities in economic performance and employment opportunities, particularly between coastal and interior regions, we must develop the connectivity of the interior zone to accelerate their CBD development. Urbanization economies encourage the emergence of virtuous circles in the transmission of innovative ideas, enabling firms to benefit from the proximity of other manufacturing units. The existence of a positive impact of urbanization economies is the reflection of the existing commercial relations between the sectors rather than the division and the exploitation of technological complementarities between sectors. 
Appendix Table A1: Specialization Index by sector and by region

\begin{tabular}{lccccccc}
\hline Governorate & Electrics & Textiles & Agro-foods & Construction & $\begin{array}{c}\text { Transportation } \\
\text { material }\end{array}$ & Chemicals & $\begin{array}{c}\text { Other } \\
\text { manufacturing } \\
\text { industries }\end{array}$ \\
\hline Tunis & 0.15 & 0.14 & 0.56 & 1.95 & 0.36 & 0.36 & 0.91 \\
Ariana & 2.81 & 0.37 & 1.14 & 0.46 & 0.98 & 0.58 & 0.94 \\
Ben Arou & 2.43 & 0.21 & 1.75 & 0.49 & 0.97 & 3.53 & 0.53 \\
Manouba & 0.65 & 2.40 & 2.98 & 0.07 & 0.33 & 1.42 & 0.43 \\
Nabeul & 1.19 & 1.64 & 0.86 & 0.06 & 3.04 & 1.13 & 1.11 \\
Zaghouan & 0.00 & 3.32 & 0.09 & 0.00 & 2.15 & 0.63 & 0.78 \\
Bizerte & 3.79 & 1.58 & 0.18 & 0.22 & 1.41 & 1.24 & 2.50 \\
Béja & 0.87 & 0.00 & 4.56 & 0.00 & 0.00 & 0.48 & 2.27 \\
Jendouba & 0.00 & 0.00 & 0.42 & 0.35 & 0.00 & 1.31 & 0.00 \\
Le Kef & 0.00 & 1.10 & 0.14 & 0.37 & 0.00 & 2.83 & 1.20 \\
Siliana & 0.00 & 3.32 & 0.35 & 0.00 & 0.00 & 0.00 & 0.00 \\
Sousse & 2.75 & 0.92 & 1.27 & 0.29 & 3.18 & 1.30 & 0.96 \\
Monastir & 0.62 & 3.30 & 0.32 & 0.12 & 0.23 & 0.75 & 1.11 \\
Mahdia & 0.04 & 2.91 & 3.10 & 0.34 & 0.09 & 0.09 & 1.34 \\
Sfax & 0.40 & 1.28 & 2.38 & 1.07 & 1.56 & 1.82 & 0.52 \\
Kairouan & 3.74 & 0.00 & 2.14 & 0.35 & 2.11 & 0.12 & 4.77 \\
Kasserin & 0.00 & 0.00 & 2.82 & 0.24 & 0.00 & 5.09 & 0.00 \\
Sidi Bou & 0.00 & 0.00 & 4.40 & 0.22 & 11.31 & 3.34 & 0.78 \\
Gabès & 0.08 & 0.52 & 1.26 & 2.28 & 3.47 & 2.40 & 0.46 \\
Medenine & 0.00 & 0.00 & 2.56 & 0.63 & 0.21 & 0.81 & 0.27 \\
Tataouin & 0.00 & 0.00 & 4.60 & 0.32 & 0.00 & 6.59 & 0.00 \\
Gafsa & 0.00 & 0.00 & 0.94 & 0.61 & 0.20 & 0.31 & 0.00 \\
Tozeur & 0.00 & 0.00 & 0.00 & 0.05 & 0.00 & 0.00 & 0.00 \\
Kebili & 0.00 & 0.00 & 0.00 & 5.09 & 0.00 & 0.00 & 0.00 \\
Total & 0.81 & 0.96 & 1.62 & 0.65 & 1.32 & 1.51 & 0.87 \\
\hline Source: & & & & & & \\
\end{tabular}

Source: Authors' calculus based on Enterprises Survey (2006).

Appendix Table A2: Regional disparities of firms number by sector

\begin{tabular}{|c|c|c|c|c|c|c|c|}
\hline \multicolumn{2}{|c|}{ Textiles sector } & \multicolumn{2}{|c|}{ Electric \& electronics } & \multicolumn{2}{|c|}{ Food products } & \multicolumn{2}{|c|}{ Chemical sector } \\
\hline Governorate & Freq, \% & Governorate & Freq, \% & Governorate & Freq, \% & Governorate & Freq, \% \\
\hline Monastir & 32.4 & Sfax & 18.4 & Sfax & 27.5 & Ben Arous & 21.7 \\
\hline Sfax & 14.8 & Ben Arous & 17.7 & Nabeul & 12.3 & Sfax & 20.8 \\
\hline Nabeul & 9.9 & Tunis & 13.6 & Tunis & 11.0 & Sousse & 17.9 \\
\hline Sousse & 9.6 & Bizerte & 10.2 & Sousse & 8.5 & Tunis & 12.3 \\
\hline Bizerte & 9.1 & Sousse & 10.2 & Ben Arous & 6.8 & Nabeul & 6.6 \\
\hline Tunis & 5.7 & Nabeul & 9.5 & Medenine & 5.5 & Monastir & 4.7 \\
\hline Manouba & 4.9 & Ariana & 5.4 & Manouba & 3.8 & Ariana & 3.8 \\
\hline Ben Arou & 4.0 & Monastir & 4.1 & Bizerte & 3.8 & Manouba & 3.8 \\
\hline Mahdia & 3.3 & Manouba & 3.4 & Kairouan & 3.8 & Zaghouan & 1.9 \\
\hline Ariana & 1.9 & Gabès & 2.0 & Ariana & 2.5 & Bizerte & 1.9 \\
\hline Zaghouan & 1.8 & Béja & 1.4 & Monastir & 2.5 & Jendouba & 0.9 \\
\hline Kairouan & 0.6 & Kairouan & 1.4 & Kasserine & 1.7 & Mahdia & 0.9 \\
\hline Gabès & 0.6 & Gafsa & 1.4 & Sidi Bouzid & 1.7 & Kasserine & 0.9 \\
\hline Le Kef & 0.5 & Mahdia & 0.7 & Gabès & 1.7 & Medenine & 0.9 \\
\hline Medenine & 0.5 & Sidi Bouzid & 0.7 & Béja & 1.3 & Gafsa & 0.9 \\
\hline Béja & 0.2 & Zaghouan & 0.0 & Mahdia & 1.3 & Béja & 0.0 \\
\hline Siliana & 0.2 & Jendouba & 0.0 & Gafsa & 1.3 & Le Kef & 0.0 \\
\hline Jendouba & 0.0 & Le Kef & 0.0 & Zaghouan & 0.8 & Siliana & 0.0 \\
\hline Kasserine & 0.0 & Siliana & 0.0 & Tataouine & 0.8 & Kairouan & 0.0 \\
\hline Sidi Bouzid & 0.0 & Kasserine & 0.0 & Jendouba & 0.4 & Sidi Bouzid & 0.0 \\
\hline Tataouine & 0.0 & Medenine & 0.0 & Le Kef & 0.4 & Gabès & 0.0 \\
\hline Gafsa & 0.0 & Tataouine & 0.0 & Siliana & 0.4 & Tataouine & 0.0 \\
\hline Tozeur & 0.0 & Tozeur & 0.0 & Tozeur & 0.0 & Tozeur & 0.0 \\
\hline Kebili & 0.0 & Kebili & 0.0 & Kebili & 0.0 & Kebili & 0.0 \\
\hline
\end{tabular}

Source: Authors' calculus based on Enterprises Survey (2006). 


\section{References}

Ayadi, M., and M. Amara (2009). 'Spatial Patterns and Geographic Determinants of Welfare and Poverty in Tunisia'. ERF Working Paper 478. Cairo: Economic Research Forum.

Amara, M., and M. Ayadi (2011). 'Local Employment Growth in the Coastal Area of Tunisia: A Dynamic Spatial Panel Approach’. ERF Working Paper 650. Cairo: Economic Research Forum.

Amara, M., and M. Ayadi (2013). 'The Local Geographies of Welfare in Tunisia: Does Neighbourhood Matter?'. International Journal of Social Welfare, 22(1): 90-103.

Ayadi, M., A. El Lahga, and N. Chtioui (2007). 'Poverty and Inequality in Tunisia: A NonMonetary Approach'. PMMA Working Paper 2007-05. Available at: www.papers.ssrn.com/sol3/papers.cfm?abstract_id $=985372$

Ayadi, M., and W. Mattoussi (2013). 'From Productivity to Exporting or Vice Versa? An Evidence from Tunisian Manufacturing Sector'. Paper presented at the UNU-WIDER Conference on Learning to Compete, 24-25 June. Helsinki.

Batisse, C. (2002). 'Dynamic Externalities and Local Growth: A Panel Data Analysis Applied to Chinese Provinces'. China Economic Review, 13(2-3): 231-51.

Enterprises Survey (2006). 'Tunisian manufacturing firms survey'. Tunis: INS.

Glaeser E. L., H. D. Kallal, J. A. Scheinkman, and A. Shleifer (1992). 'Growth in Cities'. Journal of Political Economy, 100(6): 1126-53.

Henderson, J. V. (1986). 'Efficiency of Resource Usage in City Size'. Journal of Urban Economics, 19:47-70.

Hichri, S., M. Amara, and M. Ayadi (2013). 'The Territory: What Role for the Growth of Young Tunisian Firms?'. mimeo.

INS (Institut National de la Statistique) (2013). 'Répertoire National des Entreprises'. Tunis: Ministère du Plan. République Tunisienne: Available at: www.ins.nat.tn/indexfr.php.

Jacobs, J. (1969). The Economies of Cities. New York, NY: Random House.

Marshall, A. (1920). Principles of Economics. London: Macmillan.

Plummer, A. L. (2010). 'Spatial Dependence in Entrepreneurship Research Challenges and Methods'. Organizational Research Methods, 13(1): 146-75.

Porter, M. (1990). The Competitive Advantage of Nations. New York, NY: The Free Press.

World Bank (2009). World Development Report 2009: Reshaping Economic Geography. Washington, DC: World Bank. 